\title{
I Know Where Oysters Lie
}

\author{
Sarah Jane Moore \\ sarahjane.moore@unsw.edu.au
}

\begin{abstract}
This research honours the Baludarri (Sydney Rock Oyster). It is interdisciplinary in its approach and showcases the work of Australian born artist, Sarah Jane Moore. It presents key findings from an artistic residency at UNSW in Sydney, Australia, through the modalities of image, song and text. It highlights the importance of the humble oyster and maps an art-meets-science approach where Moore's creative thinking seeks inspiration from her relationship with the work of an Indigenous scientist, Laura Parker. The oyster is Moore's living data and the work maps the deep listenings necessary to foster communities that value reefs, hold oceans as sacred and regard the oyster as a precious entity to be celebrated, protected and nourished.
\end{abstract}

\section{Acknowledgement}

The 'Eora people' was the name given to the coastal Aboriginal people around Sydney. The word Eora simply means 'here' or 'from this place'. Local Aboriginal people used the word to describe to the British where they came from and so the word was then used to define the Aboriginal people themselves. The Territory of the Gadigal people stretched along the southern side of Port Jackson (Sydney Harbour) from South Head to around what is now known as Petersham. Their southern boundary is unclear.

(Anita Heiss, Melody-Jane Gibson Barani, Aboriginal people and place accessed https://www.sydneybarani.com.au/, 1/12/2019)

Sarah Jane acknowledges Aboriginal and Torres Strait Islander peoples as the custodians of the land that we now know as Australia. She acknowledges the Gadigal clan of the Eora Nation as traditional custodians of the place that we now know as Sydney. She acknowledges the Bidjigal and Gadigal clans on whose traditional lands and sea countries the University of New South Wales, Sydney is located.

Always was, always will be Aboriginal lands and Sea Countries. 


\section{Introduction}

This story honours the Baludarri (Sydney Rock Oyster). It pays tribute to the individual shells, the soft bodies, and the pearlescent undersides. It dignifies and values the single oyster as a unique and precious organism whilst cherishing collective connections to ancient reefs that click and creak. It is a story that makes visible the vulnerable. It is a story of profound remembering. It maps and tracks the art of thinking through oysters and bears witness to the deep listening necessary to hear the oysters sing:

I know where oysters lie

I know where the cold wind blows

The stories, they survive.

(Lyrics by S. J. Moore from 'I know where Oysters lie')

Some stories endure difficult journeys and are passed down through family lines. Some emerge from collective and cultural conversations whilst others are forbidden to be told. Some stories are hidden from view whilst some emerge from and are carried by the human breath. Some stories are spoken through the wind and deeply embedded within the non-human. Some stories are spoken whilst some are sung. Ocean stories are often hidden; submerged and secretly seeded beneath watery worlds. This story was seeded in Sydney, Australia, with the Baludarri when a chance meeting with a scientist began my deep listening to and with the oyster. I met Indigenous Scientist, Laura Parker at the UNSW Kensington Campus, in November 2018, and became acquainted with her research that uses selective breeding techniques to produce climate change resistant oysters (Parker, 2009). Meeting Laura and hearing her speak about the way in which her research provided solutions, to prevent the loss of the Baludarri, fascinated me. I listened and learnt that the Baludarri was

vital to the health of marine and estuarine ecosystems, a major source of protein for nations around the globe and a cultural link for Indigenous Australians to traditional lands.

(L. Parker, Personal Communication, June 2019)

A Wiradjuri Scientist, Laura Parker has focussed her career on the impacts of climate change on marine molluscs.

My research assesses how ocean warming and acidification impact the physiology of oysters and identifies those individuals which show greater resilience. These 'resilient' oysters are then used to breed from, allowing us to climate-proof important oyster industries.

(L. Parker, Personal Communication, December 2019)

Early in our research partnership, Laura shucked an oyster in my presence. With the first turn of her flashing blade and with the deft and swift cuts of her black gloved hand, she opened the bubbling and secret world of the Baludarri to me. I searched for the beating heart of this humble, ancient creature and her body became mine. There was no return. I was captivated. Once she was known to me there was no unknowing. My worlding became the oyster:

Cultural and Pedagogical Inquiry, Summer 2020, 12(1), pp. 244-249

ISSN 1916-3460 @ 2020 University of Alberta

http://ejournals.library.ualberta.ca/index.php/cpi/index 
Like bottom dwellers, memories flow like rivers.

Families connect and seeds disperse.

I am told that it is under the microscope

That her first life stage is dance

I am told that she moves through the water column and is mobile

I am told that she flutters

In her early stages she is restless

She does not settle but rises with the tide

It is later that I see her heartbeat

It is later that I cut her.

Cut her out and remove her shell

Her flesh is soft and salty,

She bubbles and dies.

The world is our oyster.

(The world is our oyster, S. J. Moore)

\section{Oyster worlding; walking and weathering}

This process of knowing and becoming intimate and attuned to a lively world including weathering worlds is what we call worlding.

(Malone \& Moore, 2019, p. 4)

In 2019, as a result of meeting Laura, my worlding with oysters materialised and I successfully applied to become an Australian National Art and Technology (ANAT) artist within the UNSW School of Biological Earth and Environmental Science (BEES).

ANAT is a global leader brokering opportunities for artists to work with the science and technology sectors. We do this because we believe artists are essential contributors to how we imagine and shape our future.

(V. Sowry, ANAT Director, Personal Communication, August 2019)

I set up a studio, embarked on deep learning, experimental practice and the development of cultural capital (Hunter, 2014). I spent a year looking at, listening to and learning from the oyster. I generated creative research dialogues from the nexus between art and science, and my creative work was spawned from the tensions and synergies generated from conversations, fieldwork and shared time with Laura. It was artist-driven, generative, process-focussed and enacted in the Harbour city in which I lived. It felt sustainable long-term and connected.

Unlike the short-term fly-in fly-out artistic residencies that I had previously enacted in Cradle Mountain (Tasmania), Fiji (Coral Coast) and Guam, the ANAT artistic residency enabled me to focus on long-term discovery-based research dialogues. Instead of listening to local wisdoms and honouring local participants, and stories (Moore, 2018), I reached out to the oysters, the scientist and the field. Laura and I spoke weekly and shared time together at conferences, in offices, Cultural and Pedagogical Inquiry, Summer 2020, 12(1), pp. 244-249

ISSN 1916-3460 @ 2020 University of Alberta http://ejournals.library.ualberta.ca/index.php/cpi/index 
in laboratories, in cafes and boats. This methodological approach meant that I was both worlding, weathering and walking with Laura and the oysters.

My life's dance with the oyster had begun.

\section{Oyster knowing}

In ancient times the birds flew free ancestral wings did glide

oysters spawned on milky dawns and moon bird wings were wide

squid on hooks, disrupted nooks feathers they did fly

culture, water, wind and song two stories did collide

My song: 'I know where Oysters lie' gives an alternative narrative to the easily recognisable colonising stories of enterprise and industry in the early days of white settlement at Sydney Cove:

Ripped and stripped they sailed on ships dug out reefs every tide.

Lined with mortar stuck in stones

The colony she did rise

Oyster beds, oyster beds

Hacked and split and left for dead

Oyster beds, oyster beds

Broken shells and clans not fed

(The audio recording: 'I know where Oysters lie' is available via the following link) https://soundcloud.com/user-278409759/i-know-where-oysters-lie

The song sets up an encounter with the Baludarri for the listener. By telling the stories of the oysters that lie deep within the roads, the walls, the buildings of the early colony, the oysters come out of exile and are freed to live again. Richard Starr's evocative piano performance tells of dark days, starvation and the subjugation of the Eora People's Sea Country, whilst the Angela Mayou's line 'I know why the caged bird sings' is activated through melody and the human breath. Together, the piano and voice tell the little-known story of how, in the first few years of the invasion of the British on the traditional hunting and custodial lands of the Gadigal peoples, a large percentage of the oyster beds were destroyed. Carefully cultivated traditional foods for local families were hacked out, ground down and used for roads and buildings. The reawakening of Mayou's caged bird, in the lyrics of the song, helps tell the story of carnage and rekindles awareness of ancient reefs, stories and traditions.

Similarly, 'Two stories did collide' (see below) is an artwork that sets up a visual encounter with time-worn days. Shucked and split, the Baludarri burrow in the delicate softness of possum skin and fur linking land and Sea Countries. The feathers of the guinea fowl nestle alongside the hand-woven Welsh lace; in stark counterpoint with the dingy marks of charcoal that I collected from Sydney seashores after the bushfires. So too, the Ulysses butterfly alights the surface of the work and becomes a symbol of the fragility and finely tuned balance of sea and sky. Cultural and Pedagogical Inquiry, Summer 2020, 12(1), pp. 244-249 


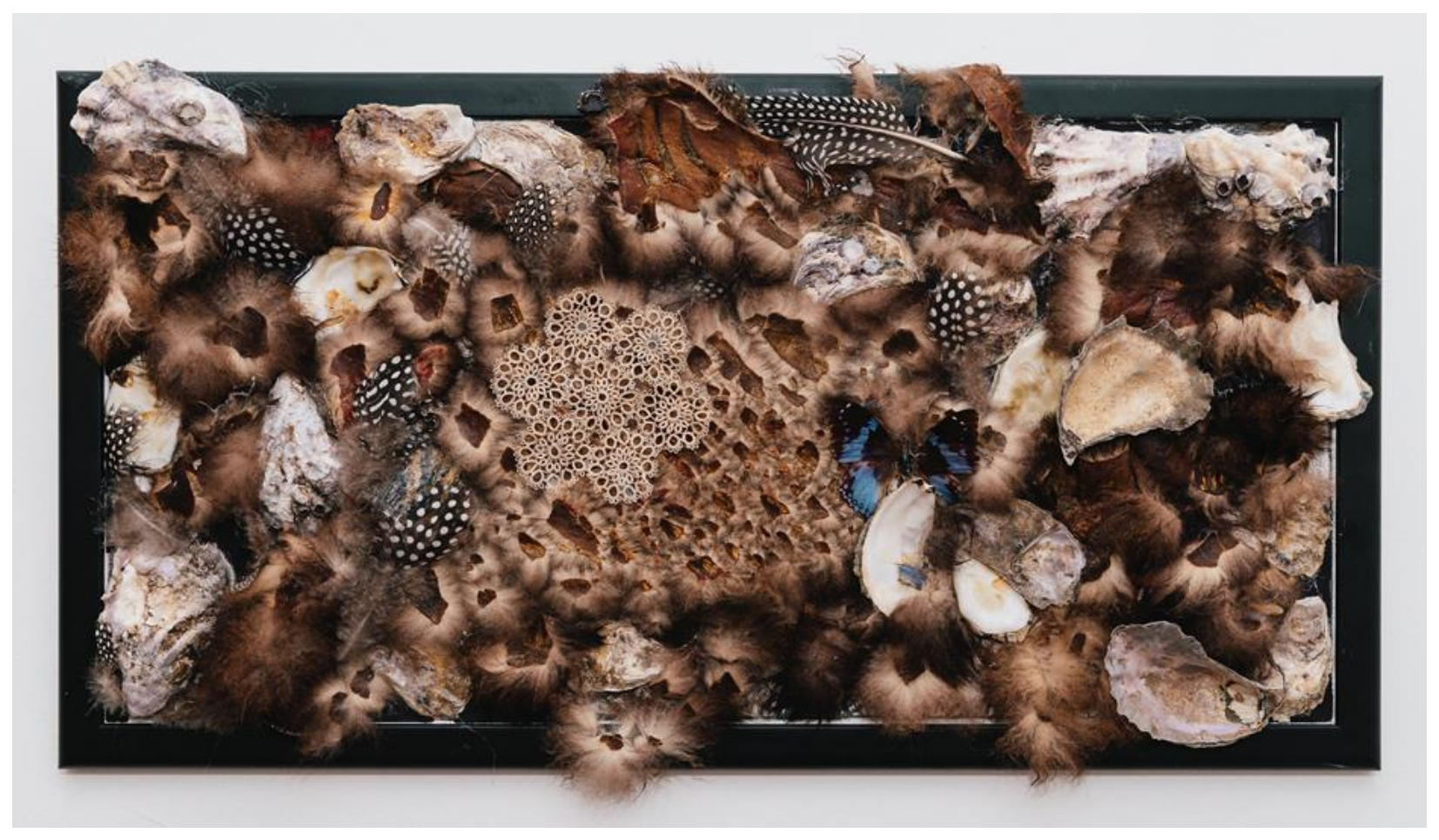

Title: 'Two stories did collide'

Date created: 2019

Medium: Baludarri (Sydney Rock Oyster shells) possum skin \& fur, Ulysses butterfly, heirloom Welsh lace, Guinea fowl feathers and charcoal on board.

Collection of: Ms. Bridgette Van Leuven, Melbourne Australia.

Photo Credit: Anton Rehrl of Corvid Photography.

Artist Statement for the Image: 'Two stories did collide' enacts encounters with land sea and sky based entities. Baludarri (Sydney Rock Oyster) shells nestle in skin and fur whilst lace, charcoal and the Ulysses butterfly balance sea and sky.

Song: 'I know where Oysters lie'

Words and Music by Sarah Jane Moore with piano performance by Richard Starr. 


\section{Conclusion}

My residency story began with a meeting of an artist and a scientist and culminated in a series of nature-based visual art works, songs and texts that shone a light on the oyster as a significant currency, a precious and vital embodiment of cultural survival, adaptation and a powerful symbol of connection to land and Sea Country (O'Sullivan, 2019).

Sarah Jane's work brings diverse knowledge systems to bear on the challenges facing the Baludarri, a culturally, scientifically and ecological important species.

(V. Sowry, ANAT Director, Personal Communication, August 2019)

Researching with and thinking through oysters can expand the notion of entity from humans to non-humans and allow us to explore the importance of mother earth, sister sea and daughter oyster.

My worlding with oysters will continue.

\section{References}

Heiss, A., Gibson, M. J. (2013). Sydney Barani Website Aboriginal People and Place. Retrieved from: https://www.sydneybarani.com.au

Hunter, M. A., Baker, W., \& Nailon, D. (2014). Generating cultural capital: Impacts of artists-inresidence on teacher professional learning [online]. Australian Journal of Teacher Education (Online), Vol. 39, No. 6, 2014:75-88.

Malone, K., \& Moore, S. J. (2019). Sensing Ecologically through Kin and Stones. The International Journal of Early Childhood Environmental Education, 7(1), 8-25.

Moore, S. J. (2018). Intercultural story sharing in Guam. The International Education Journal: Comparative Perspectives, 17(2), 30-39. https://openjournals.library.sydney.edu.au/index.php/IEJ

Moore, S. J. (2019). I know where Oysters lie lyrics. Piano accompaniment by Richard Starr.

O’Sullivan, S. (2019). I Know Where Oysters Lie opening address; The Accelerator Gallery, Culture at Work, Pyrmont, NSW.

Parker, L. M., Ross, P. M., \& O’Connor, W. A. (2009). The effect of ocean acidification and temperature on the fertilization and embryonic development of the Sydney rock oyster Saccostrea glomerata (Gould 1850). Global Change Biology, 15(9), 2123-2136.

Cultural and Pedagogical Inquiry, Summer 2020, 12(1), pp. 244-249

ISSN 1916-3460 @ 2020 University of Alberta

http://ejournals.library.ualberta.ca/index.php/cpi/index 